\title{
Strubelt, Wendelin (ed.) (2009): German Annual of Spatial Research and Policy 2008. Guiding Principles for Spatial Development in Germany
}

\section{Berlin/Heidelberg: Springer. 231 Pages}

\section{Jirí Musil}

Published online: 9 January 2010

(C) Springer-Verlag 2010

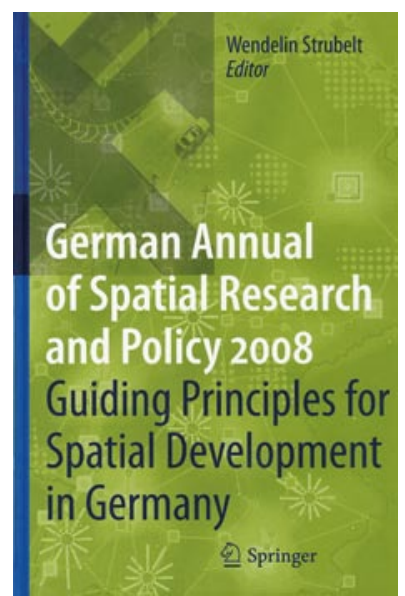

This book, edited by Wendelin Stubelt from the Federal Office for Building and Regional Planning in Bonn, is the third volume in a series of publications in which five German institutes for spatial research and planning present an overview of their scientific activities. In 12 chapters and two appendices, scholars from the institutes and a group of Polish geographers from Warsaw research institutions present the results of their studies on the conceptual, analytical, political and planning meaning of Leitbilder.

This collection is published in a period when there is felt to be a pressing need for a thorough rethinking of the aims and roles of spatial planning in its European dimensions, as well as in individual countries. Especially the question of finding the optimum balance between economic growth,

J. Musil $(\triangle)$

Újezd 15, 15000 Praha 5

Tschechische Republik

e-mail: ceu.musil@volny.cz equity, and environmental quality has become an urgent and increasingly difficult task.

The first study, by Horst Zimmermann and entitled "What is a Leitbild?", is a systematic and thoughtful discussion of the roots of the term 'Leitbild', of the practical applications of the term, of modern manifestations of Leitbilder, as well as of the difficulties of finding an equivalent English term for the concept. At the end, Horst Zimmermann expresses his scepticism regarding the usefulness of the term 'Leitbild'.

In the second study, Gabi Troeger-Weiß, Hans-Jörg Domhardt and Christoph Scheck present an empirical analysis of engines of growth beyond metropolitan areas. In the context of increasing spatial and social polarization in many European countries, it is a highly relevant chapter. The authors stress that in Germany there are numerous rural regions, and even peripheral areas, which are displaying positive and sustainable development. The most interesting part of this study is, however, the "discovery" of factors that have made such regions able to compete with other growth areas. Behind this is the creation of informal networks, bringing together business, politics, and public administration: something which might be described as an "inner-regional network of influential figures".

The third study, by Thomas Kuder, deals with the role of changing Leitbilder for the city of Greifswald. After the unification of the two parts of Germany in 1989, Greifswald started to decrease its population and the old concepts for stimulating the growth of the city failed. The study will be of particular interest to those readers who are looking for concrete examples of how to radically change the content of a Leitbild for a city, and of how to monitor the effects of the new one and mobilize public support for it.

The author of the fourth study, Rupert Kawka, investigates German experience with urban-rural partnerships. This is an issue of rising importance given the shift in the 
growth strategies in German spatial planning. Kawka starts his inquiry with a summary of empirical studies showing that the strongest regions - most often metropolitan areas generate $50 \%$ of economic growth in Germany. The strongest regions should, however, start to feel responsible for the well-being of the surrounding rural and even peripheral areas. On the evidence of so-called "demonstration projects" referred to as "supraregional partnerships", he evaluates the chances of success of the policies to promote urban-rural partnerships.

In some respects, the next study by Gerd Lintz and Peter Wirth deals with a similar issue, i.e. the importance of Leitbilder for structural change in small towns. The study is based on a comparative analysis of three small mining towns in Saxony. The most interesting part of this chapter concerns the identification of six factors for successful development and implementation of a Leitbild.

The study by Clemens Deilmann is a methodological paper concerned with the structure of the existing urban housing stock and with the impact of the composition of this housing stock on the "urban metabolism". The aim of the study is to offer a new instrument to town planners for the evaluation of the socio-spatial structure of cities.

In a short paper, Ludger Gailing and Heiderose Kilper open a discussion on a new concept in the European debate on spatial planning. Their subject is in fact a new Leitbild, a new general goal of German spatial-planning strategy summarised as "Conservation of resources, shaping of cultural landscapes". The aim here is to actively shape cultural landscapes. I believe the authors to be right in supporting the view that landscape is a key element of both individual and social well-being. The specific contribution of the authors consists in their endeavour to find practical steps - such as regional parks - for implementing this new objective into spatial-planning practices.

The next two studies deal with the German-Polish border region and with current options for the development of this area. Both the German and the Polish papers are analytically oriented and include a wealth of statistical data and maps. They summarize some important facts drawn from the main segments of data on economy, demography, and mobility which are relevant for spatial planning in a region of this type. The German paper, written by Sebastian Lentz, Günter Herfert and Annedore Bergfeld, ends with a proposal to create an attractive north-south transport infrastructure in the region along the German-Polish border, a kind of BalticAdriatic Corridor. This is a very courageous concept, and thus will raise doubts about its feasibility.

The Polish study of the border region, prepared by Grzegorz Węcławowicz, Marek Degórski, Tomasz Komornicki, Jerzy Bański, Przemysław Śleszyński and Marek Więckowski, is the most extensive in the volume. It contains 12 analytical maps and summarizes an empirical survey of the whole region. Adopting a realistic perspective, the study deals with the opportunities for, and threats to, the Polish part of the borderland area, as well as with basic directions for development which are deemed to be feasible. The concluding discussion on major constraints to implementing the aims of spatial development for this borderland area points to institutional, political, and legal barriers, which are not always mentioned in literature on spatial planning.

The volume closes with two particularly stimulating papers. The first one, written by Karl Peter Schön, introduces readers to "territorial cohesion", intended to supplement economic and social cohesion, as a new goal of the European Union. The message is clear: territory matters! Territorial cohesion aims to create equivalent living conditions and to provide coverage with general economic services throughout all parts of the EU territory, including peripheral areas. This new European Union Leitbild tolerates differences, but, at the same time, demands basic access to life chances. This seems to hold out the prospect of being a better option for the future than the older guiding principle expressed by the concept of "equivalent (or equal) living conditions". The other vital innovation mentioned by the author is dialogue with corporations as one part of the stakeholder process. These two ideas rank among the main messages contained in the Annual.

The closing paper is written by the editor, Wendelin Strubelt. It is a rich and refreshing epistemological and linguistic essay comparing the fate of the German term 'Leitbild' with other German terms already adopted into other European languages. But it also contains comments on the substance of the guiding principles underlying spatial planning. The chapter is a plea for realism and for dropping ideologically based, anti-urban guiding principles, and for acceptance of the fact that we now live in societies that have been homogenized by urbanisation. At the same time, we must rather maintain a concrete perspective when looking at the contemporary structure of our urbanized space. The old divide between rural and urban has given way to new divides, such as peripheral versus metropolitan regions, or old industrial regions versus new and growing rural regions. The need for new Leitbilder to reflect these new realities is, according to Wendelin Strubelt, obvious. And in this context he proposes retreating in our terminology away from 'Leitbild' and drawing on our Latin heritage, expressed by starting to use the terms 'concept' or 'vision'.

The Annual is an impressive collection of papers dealing with an important issue. Its importance flows from the main focus of the volume, which is on stressing the intentionality expressed in individual human lives and in human societies. I would even venture to propose that the role of intentionality in human history is slowly growing. At the same time, our responsibility for the intended - but also 
unintended - effects of our decisions and actions is also growing. We need to expend much more energy in coming up with a transparent way of formulating our intentions and goals, as well as in seeking an understanding of the probable effects of implementing our intentions and goals. However, the papers in the Annual document just how difficult a task this is, especially when we have to "translate" the guiding principles into concrete aims and actions.
The most influential streams of thought in contemporary European social sciences include the conviction that we cannot understand our societies without taking into account the intentions of both individual and collective actors. Communities, cities, and regions can be perceived as such collective actors. They cannot exist without visions. This Annual has proved just how relevant understanding this fact is for spatial planning. 